\title{
DAKWAH DAN MASALAH KONTEMPORER
}

\author{
Syafriwaldi \\ Dosen IAIN Batusangkar \\ Jln. Sudirman No. 137 Kubu Rajo, Lima Kaum Batusangkar
}

\begin{abstract}
In the science and technology currently, also the success development have penetrated all aspects of the field of life, it is not only bringing the convenience and happiness, but also to new behaviors and issues. There are many issues that long time ago was never known, never imagined; now they are true. this reality is meant by contemporary issues. During this time the theme and scope of da'wah only revolves around the problems of hablum minallah (vertical relationship), or in akhhrawi problem; Syahadat, prayer, fasting, hajj and other religious ritual themes. While the theme of other Islamic da'wah, namely hablum minannas (horizontal relationship) is not much touched on, when in fact the scope or theme of da'wah is very broad. Issues of the ummah's interests are part of the themes of Islamic da'wah, such as democracy, the problem of increasing the resources of the ummah, the problem of economic improvement, work ethic and others. They are rarely alluded in the subject of da'wah material so that da'wah seems not to stand on the earth but in the air.
\end{abstract}

Kata Kunci: dakwah, kontemporer

\section{PENDAHULUAN}

$\mathrm{K}^{\mathrm{s}}$ emajuan dalam bidang iptek dan keberhasilan pembangunan akhir-akhir ini telah merambah seluruh aspek bidang kehidupan, tidak saja membawa kemudahan dan kebahagiaan, juga menimbulkan sejumlah perilaku dan persoalan barupersoalan baru. Cukup banyak persoalan yang beberapa waktu lalu tidak pernah dikenal, bahkan tidak pernah terbayangkan, kini hal itu menjadi kenyataan. kenyataan inilah yang dimaksudkan dengan permasalahan-permasalahan kontemporer.

Kiranya sudah merupakan kewajaran dan keniscayaan setiap timbul persoalan baru maupun aktifitas baru sebagai produk dari kemajuan, umat senantiasa bertanya, bagaimana kedudukan hal tersebut dalam ajaran islam dan bagaimanakah pandangan islam terhadapnya. Pandangan islam terhadapnya boleh jadi telah termuat dalam sumber ajaran islam, kitab suci Alqur'an dan Sunnah Nabi, boleh jadi telah termuat dalam kazanah klasik karya peninggalan ulama-ulama terdahulu atau bahkan belum tersentuh sama sekali.

Untuk menjawab keraguan dan kebingungan umat tentang masalah kontemporer ini, peran dakwah dalam pengertian yang luas sangat memiliki peran yang amat strategis, sebab bagimanapun hebatnya sebuah produk kalau tidak sampai ke konsumen 
maka produk itu tidak akan bernilai.

Dakwahlah yang menjembatani bagaimana kehebatan sumber ajaran islam, atau produk ulama klasik atau bahkan produk pemikir Islam kontemporer dapat dinikmati oleh ummat sebagai konsumen.

Kemjuan ilmu pengetahuan dan teknologi serta kemajuan pembangunan dewasa ini. Baik kiranya pemahaman tentang dakwah diletakan pada proporsi yang sebenarnya, bahwa tugas dakwah bukanlah milik kiai, ulama dan pimpinan informal lainnya. Biasanya pandangan ini dilandasi suatu paham agama yang hanya melihat Nabi sebagai seorang pemimpin do'a dan imam shalat tanpa memandang beliau sebagai social reformer, dan bangsawan pimpinan Negara dan ummat yang flural dan masih banyak contoh yang lainnya.

\section{IDENTIFIKASI KONTEMPORER}

MASALAH

\section{Masalah Fiqh, Akidah dan kemasyarakatan}

Adapun masalah kontemporer yang muncul kepermukaan yang berhubungan dengan masalah fiqih, Akidah dan kemasyarakatan, di antaranya adalah :

1). Dibidang Ibadah

1. Shalat Jum'at bagi musafir di kapal

2. Shalat dalam satu masjid bertingkat
3. Shalat dan puasa di daerah yang waktu siang dan malamya tidak seimbang

4. Mentasharufkan dana zakat untuk kegiatan produktif dan kemaslahatan umum

5. Intensifikasi pelaksanaan zakat

6. Pemberian zakat untuk beasiswa

7. Penentuan wal ramadhan, awal syawal/idul fitri dan awal dzulhijjah/Idul Adha

8. Ibadah haji hany sekali seumur hidup

9. Istita'ah dalam melaksanakan ibadah haji

10. Miqat haji dan umrah

11. Miqat Makani

12. Mabit di Mudzalifah

13. Mabit di Mina

14. Pil anti haid

15. Qira'at sab'ah

16. Penulisan Alqur'an selain dengan huruf Arab

17. Do'a Da'aful bala'

18. Kepeloporan pejabat dalam melaksakan ibadah

19. Pelaksanaan shalat jum'at dua gelombang

20. Haji bagi narapidana

21. Wakaf uang

22. Zakat penghasilan

2). Faham Keagamaan

1. Paham Syia'ah

2. Ahmaddiyyah Qadyiah

3. Islam Jama'ah

4. Darul Arqam

5. Aliran yang menolak sunnah dan hadits Rasul 
6. Masalah jama'ah, khalifah, dan baiat

7. Pendangkalan agama dan penyelahgunaan dalil-dalil

8. Malaikat Jibril mendampingi manusia

3). Sosial Kemasyarakatan

1. Nyanyian dengan menggunakan ayat-ayat Alqur'an

2. Hidup sedehana

3. Penyalahgunaan Narkotika

4. Penyalahgunaan ecstasy dan zat-zat sejenis lainnya

5. Hukum alcohol dalam minuman

6. Makanan dan minuman yang bercapur dengan barang haram/najis

7. Hukum memerankan Nabi/Rasul dan orang suci dalam Film

8. Prosedur pernikahan

9. Pengucapan taklik talak pada waktu upacara akad nikah

10. Pernikahan campuran

11. Nikah Muth'ah

12. Talak tiga sekaligus

13. Iddah wafat

14. Adopsi (Pengankatan anak)

15. Kependudukan, kesehatan dan pembangunan

16. Pendayagunaan tanah warisan

17. Memindahkan jenazah

18. Memusiumkan mayat

19. Panti pijat

20. Memakan daging kelinci

21. Memakan dan membudidayakan kodok

22. SDSB I dan II

23. Penanggulangan penularan HIV dan AIDS
24. Tuntunan syari'at Islam dalam bersikap, bergaul dan merawat penderita AIDS

25. Kedudukan Waria

26. Perayaan natal bersama

27. Reksadana syari'ah

28. Makan dan budidaya cacing dan jangkrik

29. Aborsi

30. Penggunaan organ tubuh, ari-ari dan air seni manusia bagi kepentingan obat-obatan dan kosmetika

31. Risywah (Suap), ghulul (Korupsi) dan hadiah lepada pejabat

32. Hak-hak asasi manusia (HAM)

33. Pengiriman tenaga kerja wanita ke luar negeri

34. Bias jender

35. Penetapan produk halal

36. Pornografi dan porno aksi

37. Kepiting

38. Hak Cipta

39. Penyerangan Amerika dan sekutu terhadap Irak

4). Ilmu Pengetahuan dan Teknologi

1. Penyemblihan hewan secara mekanis

2. Vasectomi dan Tubectomi

3. Wasiat menghibahkan kornea mata

4. Operasi perubahan dan penyempurnaan kelamin

5. Pengambilan dan penggunaan kutup jantung

6. Bayi tabung dan inseminasi buatan

7. Penyakit Kusta 
8. Kloning

9. Produk penyedap rasa (monosodium glutamate, MSG) dari PT. Ajinomoto Indonesia yang menggunakan Bacto Soytone

10. Produk penyedap rasa (monosodium glutamate, MSG) dari PT. Ajinomoto Indonesia yang menggunakan mameno

11. Penggunaan vaksin volio khusus (Dirjen Bimbingan Masyarakat Islam dan Penyelenggaraan Haji Dep. Agama, Himpunan Fatwa Majelis Ulama Indonesia 2003 : $15)$.

$\begin{array}{rcr}\text { Inilah beberapa masalah } \\ \text { kontemporer } & \text { yang } & \text { sempat }\end{array}$
diperbincangkan oleh umat islam Indonesia khususnya dan masalahmasalah ini telah diakomodir oleh Majelis Ulama Indonesia dengan mengeluarkan fatwa bagaimana hukum dan pandangan islam tentang masalah-masalah tersebut.

\section{Globalisasi}

Globalisasi adalah issu di era kontemporer yang ahrus disikapi dengan cermat. Pada dua dasawarsa ini, arus globalisasi tersebut brgerak begitu cepat, besar, kuat dan sering kali radikal. Ia dating menmbus batas kedaulatan nasional setiap Negara, baik itu dialami oleh Negara-negara maju dan lebih-lebih lagi terhadap Negara berkembang. Negara-negara itu semakin terkait satu sama lainnya dalam pintalan ekonomis, teknologis dan juga politis. Dari sana dapat dirasakan sumber-sumber teknologi serta informasi bergerak dan berpindah-pindah secara lebih deras dan lancer dari satu Negara kenegara lainnya atau dari satu wilayah ke wilayah lainnya.

Globalisasi pada hakekatnya "Mengacu pada perkembanganperkembangan yang cepat di dalam teknologi komunikasi, transfortasi, informasi yang bisa membawa bahagian-bahagian dunia yang jauh menjadi hal-hal yang bisa dijangkau dengan mudah (Hastings Donnan, 1994 : 1). Globalisasi yang melahirkan "Dunia tanpa tapal batas" dimana factor-faktor lintas batas antar benua mampu ditembus dengan teknologi imformasi dan komunikasi.

\section{Era Multimedia}

Era multimedia merupakan produk teknologi informasi adalah masalah yang muncul diera kontemporer. Kehadiranya merupakan tantangan dan peluang. "John Neisbitt mengungkapkan "We are moving toward the capability to communicate anything to anyone, anywhere, anyform voice, data, textor emage at the speed of light (Kita bergerak ke arah kemampuan berkomunikasi apa saja kepada siapapun, dimanapun, berbentuk apapun (baik itu) suara, data, tulisan, atau gambar (Citra) dengan (menggunakan) kecepatan suara (Chairil Anwar, 2000 : 65-66) Pada kesempatan lain John Neisbitt mengatakan, "The new source of fower is not money in the hands of a 
few but information in the hends of money".

Ungkapan tersebut merupakan sekelumit gambaran era informasi yang mengglobal dan yang menghadang dihadapan kita (umat islam) dimanapun berada dimuka bumi ini.

\section{SOLUSI DAKWAH TERHADAP MASALAH-MASALAH KONTEMPORER}

\section{Re-understanding dakwah}

Selama ini tema dan lingkup dakwah hanya berkisar dalam masalah-masalah hablum minallah (hubungan vertical), atau masalah ukhrawi belaka ; Syahadat, shalat, puasa, haji dan tema-tema ritual keagamaan lainnya. Sementara tema dakwah Islam lainnya, yaitu hablum minannas lainnya (hubungan horizontal) tidak banyak disinggung, padahal sebenarnya cakupan atau tema dakwah sangatlah luas. Masalah-masalah kepentingan ummat adalah bahagian dari tema-tema dakwah islam, misalnya demokrasi, masalah peningkatan sumber daya ummat, masalah peningkatan ekonomi, etos kerja dan lain-lain. Hal ini jarang disinggung dalam bahasanbahasan materi dakwah sehingga dakwah seakan tidak berpijak di bumi tetapi mengangkasa.

Di era kontemporer ini, juru dakwah harus mampu berdialog dengan masalah-masalah pelik atau masalah-masalh kontemporer dan secara aktif mengisinya dengan subtansi dan nuansa-nuansa Islami. Hal ini hanya bisa dilakukan bila juru dakwah mengetahui arus globalisasi secara benar dan tidak tertinggal dengan informasi actual. Pengetahuan global dan informasi actual merupakan sebuah keniscayaan dimiliki oleh seorang juru dakwah. Di zaman kontemporer ini hal ini menjadi kekuatan. Seperti diungkapkan oleh futurulog John Neisbitt : "The New source of fower is not maney ini the hands of a few but information in the hands of many." (Kekatan baru dewasa ini bukanlah harta karun di tangan segelintir manusia tetapi kekuatan adalah jaringan informasi di tangan banyak manusia). Relevan juga apa yang dikatakan oleh ahli managemen Amerika Drucker bahwa "The productivity of knowledge became the key to productivity, competitive strength, and economic achievement. Knowledge has already become of primary industry, the industry that suppliesthe economy the essential and central resources of production." (Productifitas ilmu pengetahuan telah menjadi kunci productivitas daya saing dan prestasi ekonomi. Ilmu pengetahuan telah menjadi industri utama yakni industri yang melengkapi kebutuhan ekonomi dengan sumbersumber productivitas utama yang maha penting" (Samsul Munir Amin, $2008: 12$ ). 


\section{b. Memilih Materi Dakwah yang Relefan}

Dalam dua atau tiga terakhir ini, aktifitas keagamaan pada umumnya ditandai oleh usaha mengubungkan antara ajaran agama dan pembangunan masyarakat. Dalam hal ini ajaran agama diharapkan dapat mendorong masyarakat untuk lebih berpartisipasi dalam pembangunan, sambil membentengi penganutpenganutnya dari segala macam dampak negative yang mungkin terjadi akibat pembangunan. Kecendrungan ini terus berjalan seiring dengan perkembangan ilmu pengetahuan dan pembangunan, pada sisi lain tidak dapat dipungkiri bahwa masih sering terdengar uraian-uraian keagamaan yang tidak sejalan dengan kecendrugan tersebut.

Bapak Prof. DR. Quraish Shihab meberikan ilustrasi. "Marilah kita mengambil contoh dari uraianuraian menyangkut hijrah yang disana-sini masih terdengar. Uraianuraian tersebut dapat dibagi dalam dua kategori. Pertama : uraian yang bersifat Supranatural, seperti "merpati" dan "Sarang laba-laba" yang tiba-tiba menutupi mulut gua tempat Nabi Saw bersembunyi, "daun-daun" serta merta lebat disekeliling gua dan lain-lain yang tidak semuanya dapat dipertanggung jawabkan dari segi riwayat apalagi dari segi ilmiah. Kedua, uraian yang mendukung pembangunan masyarakat, seperti persiapan dan perencanaan dalam berbagai segi, 'sikap-sikap Nabi dan Abu baker ra.' Selama dalam perjalanan "kerjasama nabi" dengan penunjuk jalan yang "non Muslim", dan sebagainya (M. Quraish Shihab, 2008: 60)

Uraian-uraian kategori pertama bila berulang-ulang disampaikan kepada umat, sama sekali tidak mendukung peranan yang diharapkan dari agama dalam pembangunan. Ia bukan saja mengecilkan upaya dan jerih payah Nabi sebelum dan pada saat berhijrah, tetapi ia juga mengaburkan sejarah bahkan ajaran agama. Sebetulnya, "Islam tidak hanya mengandalkan hal-hal supranatural dalam pembuktian ajarannya dan dalam mencapai perjuangannya. Walaupun pada hakekatnya ini tidak berarti pengingkaran dari "uluran tangan Tuhan". Ia pernah, masih akan, dan selalu akan ada, tetapi ia tidak akan diperoleh dengan sekedar percaya, do'a, atau bahkan pelaksanaan Syari'at saja. Para sahabat yang sangat mendambakannya dan yang telah dipimpin langsung oleh Nabi, pernah tidak memperolehnya karena mereka gagal memenuhi syaratsyaratnya."

Menjelang berkecamuknya perang uhud, Allah Swt berpesan : "Apabila kamu bersabar, bersiap siaga dan bertakwa (Melaksanakan tuntunan Allah menyangkut syari'at dan sunnatullah) maka jika mereka datang menyerang kamu dengan seketika itu juga, niscaya Allah akan membantu kamu dengan lima ribu 
malaikat yang memakai tanda (QS. 3 : 125). "Turunya malaikat" adalah peristiwa supranatural dan merupakan sebahagian dari "Uluran tangan ilahi" yang pernah mereka peroleh dalam perang badar (QS. 8 : 12). Betapa Nabi Muhammad Saw dan para sahabat akan merasa senang bila kemenangan akan mereka peroleh sebagaimana pada peperangan badar. Tapi dalam kenyataannya mereka kalah dalam peperangan ini disebabkan syarat-syarat yang ditetapkan Tuhan ketika itu tidak mereka penuhi.

Memilih materi dakwah yang relefan di era globalisasi dan kontemporer ini sangat menentukan. Memperkenalkan islam dengan argumen-argumen logis dan sistematis tanpa mengabaikan hal-hal yang berbau supranatural tapi tetap dalam koridor proforsional.

\section{c. Komitment Dengan Islam Pada Era Globalisasi}

Persoalan globalisasi merupakan sebuah kemestian yang tidak bisa ditolak kehadirannya, jadi tidak beralasan kalau ada asumsi menerima atau menolak kehadirannya. Kebenaranya adalah menerima kehadiran dunia global ini dengan memamfaatkannya secara positif demi memaksimalkan keuntungan dan meminimalisir dampak negatif yang ditimbulkan sehingga terhindar dari kerugian-kerugian yang tidak diharapkan.

Pada hakekatnya umat Islam adalah bahagian yang integral dengan dengan kebudayaan lainnya saling mempengaruhi. Dalam kontek hubungan saling mempengaruhi itu akan selalu muncul pertanyaan : Sejauh mana umat Islam dipengaruhi oleh dunia global atau sebaliknya sejauhmana umat islam mempengaruhi percaturan global itu. Islam punya kepentingan untuk mempengaruhi percaturan global, bagamaina nilainilai keislaman menghiyasi percaturan global. Dakwah islam harus masuk ke jantung percaturan global. Komitment keislaman justru merupakan keuntungan adanya globalisasi. Nilai-nilai keislaman bisa masuk kedalam ruang tanpa tapal batas di setiap penjuru di dunia ini.

Sebenarnya istilah globalisasi bagi Islam bukanlah hal yang asing bahkan istilah globalisasi itu adalah milik islam. Istilah ini semenjak islam itu ada. "Al-Qur'an sendiri sejak 14 abad tahun yang lalu telah mengajarkan pandangan secara global melalui ajaranya mengenai keberadaan Allah SWT sebagai Rabbul'alamin (Tuhan seluru Alam), dan kerasulan Muhammad sebagai "Rahmatallil'alamin". Juga AlQur'an sebagai "Hudallinnasi" semuanya ini tanpa membedakan bangsa-bangsa, ras, etnik, sub etnik, negara dn sebaginya." (Solli Lubis, 1997: 51)

Dalam surat Al-Hujarat ayat 14 Allah SWT berfirman : "dan kami jadikan kamu bersukusuku dan berbangsa-bangsa supaya kamu saling kenal, 
sesungguhnya yang paling mulia diantara kamu adalah orang yang paling bertaqwa diantara kamu."

Globalisasi menurut pandangan Islam mencakup komponen yang luas. Ia meliputi manusia, binatang, tumbuh-tumbuhan dan unsur makhluk lainnya. Seperti Bumi, air, udara dn lain-lainnya, sebagai lingkungan hidup manusia.

\section{d. Dakwah Multimedia Merupa- kan Sebuah Keniscayaan}

Kemajuan teknologi informasi telah melahirkan komponen-komponen teknologi mutaakhir seperti : siaran-siaran langsung melalui satelit, internet, memakai kabel, metode cetak yang lebih cepat dan lebih murah serta penegiriman surat-surat kabar, gambar, tulisan, suara dan lainlain melalui elektronika. Kenyataan ini tidak bisa ditolak, mau tidak mau harus diterima. Dakwah islam menerima kenyataan ini sebagai tantangan yang harus diterima dengan teliti, cermat dan dikritisi sehingga tantangan ini bisa diambil keuntungan-keuntungan atau paling tidak dakwah bisa meminimalkan dampak kerugian yang ditimbulkan. Teknologi-teknologi canggih, memungkinkan kita lebih bebas memilih serta mengontrol apa yang kita pilih untuk diakses, dibaca, diliha, dan didengar. Kemajuankemajuan teknologi atau multimedia tersebut. Menurut hemat penulis harus bisa dimamfaatkan untuk kepentingan dakwah islam. Jika peneyebaran agama islam tidak menggunakan teknologi multimedya mutaakhir, maka dakwah islam akan tertinggal dan hal ini tentu akan mengakibatkan kerugian bagi perkembangan dakwah islam. Tinggal bagaimana cara yang tepat dan baik penggunaan mediamedia mutaakhir tersebut untuk kepentingan dakwah dengan nilainilai yang positif.

Sebenarnya penggunaan media, katakanlah seperti internet sebagai media dakwah, tentu sebuah keniscayaan yang tidak bisa dikesampingkan begitu saja. Memang di dalam internet terdapat faktorfaktor negatif, tetapi jika diantisipasi sedemikian rupa dari internet akan didapat mamfaat yang sangat signifikan bagi penyebaran informasiinformasi dakwah. Beriku beberapa lembaga dan institusi islam, kini telah memiliki situs dan website sebagai penyebaran informasinya. Misalnya universitas Sain Al-Qur'an (UNSIQ) Wonosobo, memiliki Website http://www.unsiq.com.id.

Disamping itu dakwah islam harus bisa menyelaraskan dengan media-media komunikasi modern untuk penyebaran pesan-pesan dakwah islam kepada masyarakat luas (Samsul Munir Amir, 2005 : 9) bagamimanpun, dakwah membutuhkan multimedia yang modern untuk bisa menyebarkan nilai-nilai islam kepada masyarakat modern pada era globalisasi saat ini, jika tidak maka dakwah dengan sendirinya akan ketinggalan. 
Sekarang tinggal bagaimana para juru dakwah atau para pelaku dakwah menggunakan media-media komunikasi modern sedemikian rupa untuk hal-hal yang konstruktif dan bermamfaat untuk kepentingan dakwah.

\section{PENUTUP}

e. Kemajuan dalam bidang iptek dan keberhasilan pembangunan akhirakhir ini telah merambah seluruh aspek bidang kehidupan, tidak saja membawa kemudahan dan kebahagiaan, juga menimbulkan sejumlah perilaku dan persoalan baru-persoalan baru. Cukup banyak persoalan yang beberapa waktu lalu tidak pernah dikenal, bahkan tidak pernah terbayangkan, kini hal itu menjadi kenyataan. kenyataan inilah yang dimaksudkan dengan permasalahan-permasalahan kontemporer.

f. Masalah kontemporer yang muncul kepermukaan dan langsung bersentuhan dengan masyarakat Islam, khususnya di Indonesia aadalah pertama Yang berhubungan dengan Masalah Fiqh, Akidah dan kemasyarakatan, kedua Yang berhubungan dengan masalah Globalisasi, ketiga Yang berhubungan dengan era multimedia.

g. Perlu adanya pemahaman ulang terhadap konsep dakwah dalam penegrtian yang umum. Selama ini tema dan lingkup dakwah hanya berkisar dalam masalah-masalah hablum minallah (hubungan vertical), atau masalah ukhrawi belaka; Syahadat, shalat, puasa, haji dan tema-tema ritual keagamaan lainnya. Sementara tema dakwah islam lainnya, yaitu hablum minannas lainnya (hubungan horizontal) tidak banyak disinggung, padahal sebenarnya cakupan atau tema dakwah sangatlah luas. Masalah-masalah kepentingan ummat adalah bahagian dari tema-tema dakwah islam.

h. Pemilihan materi yang tepat dan relefan dengan kondisi audien hari ini perlu mendapat perhatian serius dari pelaku dakwah. Islam tidak hanya mengandalkan hal-hal supranatural dalam pembuktian ajarannya dan dalam mencapai perjuangannya. Walaupun pada hakekatnya ini tidak berarti pengingkaran dari "uluran tangan Tuhan". Ia pernah, masih akan, dan selalu akan ada, tetapi ia tidak akan diperoleh dengan sekedar percaya, do'a, atau bahkan pelaksanaan Syari'at.

i. Persoalan globalisasi dan multimedia sebagai produk Teknologi Industri Informatika merupakan sebuah kemestian yang tidak bisa ditolak kehadirannya, sikap menerima kehadiran dunia global ini dengan memanfaatkannya secara positif demi memaksimalkan keuntungan dan meminimalisir dampak negatif yang ditimbulkan 
sehingga terhindar dari kerugian-

kerugian yang tidak diharapkan

\section{DAFTAR KEPUSTAKAAN}

Anwar, Chairil, Islam dan tantangan kemanusiaan Abad XXI, Yogyakarta, Pustaka Pelajar, 2000

Departemen Agama RI, Al-Quran dan Terjemahnya, Semarang, Toha Putra, 1995

Dirjen Bimbingan Masyarakat Islam dan Penyelenggaraan haji Dep. Agama, Himpunan Fatwa Majelis Ulama Indonesia, Jakarta, 2003.

Hafidhuddin, Didin, Dakwah Aktual, Jakarta, Gema Insani, 1998

Lubis, M. Solli, Ummat Islam Dalam Globalisasi, Jakarta, Gema Insani Press, 1997.

Munir Amin, Samsul, Rekontruksi Pemikiaran Dakwah Islam, Jakarta, Amzah, 2008.

Nasution, Harun, Islam Ditinjau Dari Berbagai Aspeknya, Jakarta, UI Press, 2002

S. Ahmad, Akbar dan Donnan, Hastings, Islam Globalization and Postmodernity, London, Routledge, 1994.

Saeful Muhtadi, Asep dan Ahmad Syafei, Agus, Methode Penelitian Dakwah, bandung, Pustaka Setia, 2003

Salmadanis, Filsafat dakwah, Jakarta, Surau, 2003

Samsul Munir Amir, "Pemamfaatan Media Komunikasi dan Informasi Untuk Kepentingan Dakwah Islam". Makalah disampaikan dalam seminar Akademik Ramadhan 1426 H,
Wonosobo: LP3M UNSIQ, 15 Oktober 2005.

Sayyid al Wakil, Muhammad, Prinsip dan Kode Etik Dakwah, Jakarta , Akademi Pressindo, 2002

Shihab, M. Quraish, Lantera Alqur'an, Jakarta, PT. Mizan Pustaka, 2008 